\title{
Mobile banking in South Africa: A review and directions for future research
}

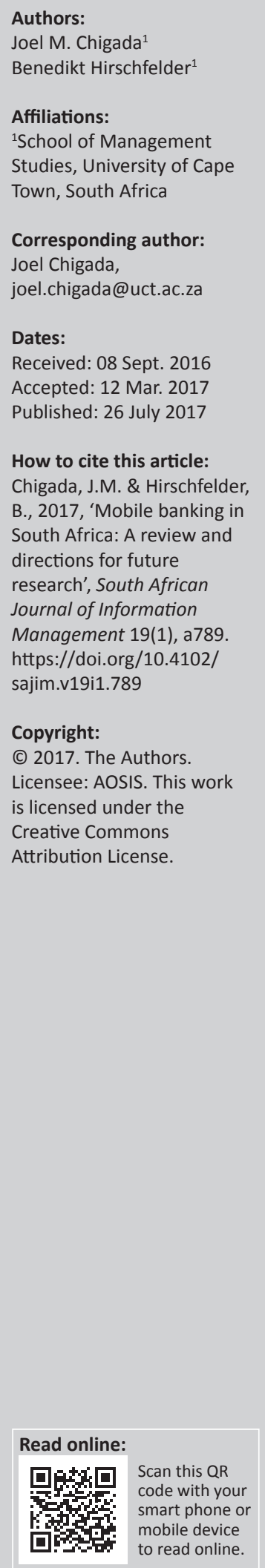

Background: The purpose of this study was to review existing research on mobile banking diffusion and investigate the adoption of mobile banking in sub-Saharan Africa (SSA).

Objectives: Based on the failure of the M-Pesa in South Africa, this article also attempted to determine why mobile money service systems are difficult to apply transnationally.

Method: This was a literature survey, analysing mobile money literature during the period 2006-2016. Because of the current explosiveness of mobile money in SSA, the focus of this literature survey was limited geographically to South Africa, Zimbabwe and Kenya.

Results: The results of the literature survey and the real-world examples mainly show that a transnational application of mobile money service systems is difficult to implement.

Conclusion: This research elucidates the demand and need for mobile money service systems in SSA while underlining the explosiveness promoted mainly by rapid technological progress.

\section{Introduction}

Web 2.0 educed a widely recognised sales channel in Business-to-Consumer and business-tobusiness. Because of the consequently connected online payment system, the banking industry adopted and integrated online transactions into their daily business, and online banking has become a popular alternative to traditional banking (Akhter 2015; Barbesino, Camerani \& Gaudino 2005; Laukkanen \& Pasanen 2008). A relatively new trend, mobile banking, developed worldwide with mobile phone mobilisation. Mobile banking is defined as any mobile interaction with a moneymanaging institute, not necessarily a bank, which allows customers to deposit, send and withdraw money (Laukkanen \& Pasanen 2008; Tobbin 2012). The Online Dictionary (2017) defines online banking as any banking transaction conducted over the Internet through a financial institution's website under a client's private profile. Common electronic devices used are mobile phones, smartphones and tablets. Mobile banking is a subset of Internet banking and a portable extension of it, increasing flexibility for customers and improving the services of a bank (Aker \& Mbiti 2010).

With regard to research in the mobile banking field in Africa, the following key points were taken into consideration. In urban areas, the density of smartphone distribution is relatively high in comparison to rural areas where the lack of connectivity options impedes the distribution (Poushter \& Oates 2015). Because of this, Africa's mobile Internet penetration is relatively low in relation to the rest of the world (Internetlivestats 2016). According to the Internet Society (2015), subdividing Africa into sub-Saharan Africa (SSA) and the Middle East and North Africa demonstrates that particularly in SSA, the penetration rate is comparatively low (Table 1).

Besides the locational circumstances, the affordability of mobile phones or telecommunication devices (smartphones or tablets) must also be considered (Brown 2014). Finally, the necessity of a bank account plays a significant role in mobile banking, particularly in the low-income class (Tobbin 2012). With regard to the points above, South African marketing practitioners have recognised this low-income banking problem and concentrated on money transfers without affiliation to a bank (Shoprite 2016) and money transfers via mobile communication companies, which assume the functions of a bank (Abbott 2015; Tobbin 2012).

Although these opportunities provide alternatives for the unbanked population, rapid technological progress predicts a promising future for mobile banking. Indeed, it has been reported that:

The technological service access methods have already bypassed the traditional branch-based retail banking and as a consequence technology has become an increasingly essential element in the competing markets of financial services. (Laukkanen \& Pasanen 2008:87) 
TABLE 1: African mobile Internet penetration.

\begin{tabular}{lcc}
\hline Variable & Sub-Saharan Africa (\%) & $\begin{array}{c}\text { Middle East and } \\
\text { North Africa (\%) }\end{array}$ \\
\hline Internet users & 17 & 39 \\
Mobile Internet penetration & 8 & 23 \\
3G population coverage & 35 & 72 \\
\hline
\end{tabular}

Source: Internet Society, 2015, Global internet report 2015, viewed 25 April 2017, from http://www.internetsociety.org/globalinternetreport/\#main-content

After eight years, are these insights applicable to Africa, considering the slower technological penetration? In this article, the researchers explored the following research questions concerning the literature on the implementation and adoption of mobile money in SSA, specifically in South Africa:

- Why do alternatives such as the Kenyan mobile money service provider, M-PESA, have such a large clientele?

- Which factors are crucial in the adoption of mobile money transfer systems/mobile banking?

- How do South Africans, particularly in the lower-income segment, operate with their money?

This research addressed these and related questions in its review of low-income mobile banking perspectives in SSA and elucidate the mobile banking situation in South Africa.

\section{Research methodology and design}

A systematic literature review approach was conducted where empirical data were collected through desktop research; thus, researchers were concerned about collecting data for the 20062016 time frame. In addition, systematic literature review allowed the researchers to formulate research questions, set inclusion/exclusion criterion and infused meta-analysis to analyse, synthesise and disseminate the findings. For this research, data were collected, analysed and interpreted using a quantitative research methodology. Data were collected from existing literature for the period 2006-2016. The researchers analysed quantitative findings from other studies in order to understand the concept of mobile banking discussed in the current study. Several studies on mobile banking in SSA were included in this study; thus, meta-analysis was infused in the study for standardised statistical procedures (see Table 2: Metaanalysis of findings). In this research, the researchers adopted a causal-comparative and descriptive research design to reveal cause and effect relationships between variables in mobile banking (van Wyk 2012). The causal-comparative and descriptive research designs helped to address the 'why' and 'how' type of research questions that informed this study. The objective was to unravel reasons why there was a slow uptake of mobile banking in SSA. However, the study also revealed that there were SSA economies that had successfully implemented these mobile money systems. The only exception was the South African project on the implementation of M-PESA which failed.

\section{South African context of mobile banking}

According to Koech (2012), in SSA, many countries exhibit a higher subscription to mobile phones than bank accounts. In
TABLE 2: Mobile phone diffusion in Africa 2014.

\begin{tabular}{lcc}
\hline Country & Own a mobile phone (\%) & Make or receive mobile payment (\%) \\
\hline Zimbabwe & 93 & 47 \\
Nigeria & 89 & 15 \\
Senegal & 84 & 30 \\
Ghana & 83 & 15 \\
Kenya & 82 & 61 \\
Tanzania & 73 & 39 \\
Uganda & 65 & 42 \\
\hline
\end{tabular}

Source: Based on: Gambanga, N., 2016b, Latest POTRAZ report shows leaps in LTE \& increase in Zimbabwe's internet penetration, viewed 1 March 2017, from http://www.techzim.co. zw/2016/01/latest-potraz-report-shows-increase-in-zimbabwes-internet-penetration/; zW/2016/01/latest-potraz-report-shows-increase-in-zimbabwes-internet-penetration/; March 2017, from http://www.techzim.co.zw/2016/01/mobile-money-subscriberszimbabwe-increase-7-1/; Poushter, J. \& Oates, R., 2015, 'Cell phones in Africa: Communication lifeline texting most common activity, but mobile money popular in several countries', viewed 22 April 2016, from http://www.pewglobal.org/2015/04/15/cell-phones-in-africacommunication-lifeline/

this context, the World Bank forecast a bright future for mobile banking as a new era of financial services, particularly in developing countries. South Africa exhibits a relatively high percentage of households with bank accounts (51\% - 80\%); thus, this high rate of bank account holders works against any ideas to transform the traditional banking services into mobile money. South Africa has a high mobile phone ownership (89\%) and, consequently, matured mobile money services. Thus, South Africa symbolises a suitable research field (Abbott 2015; Koech 2012; Poushter \& Oates 2015). Mobile banking in South Africa serves as an important interface between banks and the lower-income population by providing useful transfer, saving and investment opportunities.

The researchers suggest that mobile banking in South Africa serves the following key functions: integration into a bank system, simplification of banking, enhancement of financial opportunities and improved control of money operations. The following sections of this article review these functions and elucidate focal points. Thereafter, two real-world applications illustrate the actual state of mobile money and, finally, limitations and suggestions for future research are discussed.

\section{Integration into mainstream banking systems}

Banking has been in existence for thousands of years (Vaupel \& Kaul 2016). Banks operate mainly as service providers, for example, for cash businesses and in-bank lending and have numerous functions such as monetary functions (payment transactions), investment functions (securities) and economic functions (Vaupel \& Kaul 2016). The acceptance of deposits and other objects of value as well as lending are classical functions of a bank. Whereas the theory of John Maynard Keynes underlines the importance of the value stability of currencies (Mankiw 2015), the theory of Milton Friedman, mainly associated with monetarism, underlines the importance of price stability that is regulated by the government to control the amount of money in circulation (Mankiw 2015). Monetarism assumes that the combination of the government and the central bank and the accomplished money supply/control influence the gross domestic product. Therefore, banks play an important role regarding economic growth and control (Mankiw 2015). 
In the period 2002-2008, South Africa as the second largest economy in Africa experienced its fastest expansion since the establishment of democracy in 1994 with an average growth rate of $4.5 \%$ (Ferreira 2016). However, this growth is declining because of the increasing gap between the rich and poor, lowskilled labour forces, the high unemployment rate, deteriorating infrastructure and the high corruption and crime rates (Ferreira 2016). The lower-income class in particular is becoming progressively appealing to banks because of: (1) growing market power, (2) growing political power, and (3) technological progress (Inglesi-Lotz, Van Eyden \& Du Toit 2014; Moloi 2014; Visagie 2013). In the following sections, the researchers review each key point and elucidate how together they precipitate integration into the South African bank system.

\section{Growing market power of the lower-income class}

The growing market power of the lower-income class in South Africa is first defined. According to Visagie (2013) middle-class households (an average of four people) in South Africa have a total income of R5600 to R40 000 per month after direct income tax. Every household that has an income of less than R5600 falls into the lower-income class category. A report by BusinessTech (2016) states that $70 \%$ of the South African population earns less than R6000 per month, and thus, they fall into the lower-income class category. With regard to such a collective buying power but single buying weakness, savings accounts are rare because of the meagre lifestyle. Particularly in the lower-income class, saving schemes called stokvel ${ }^{1}$ are more popular than traditional saving systems (UCC 2016). South African banks recognise this trend by offering tailored banking applications in order to integrate this income class.

\section{Growing political power of the lower-income class}

South Africa is a democratic country in which the political landscape is characterised by different political parties. Prior to the country's attainment of independence in 1994, the lower-income members of society were voiceless because of the oppressive apartheid regime laws (Moloi 2014). There has been a great paradigm shift in the political dispensation of the country, and previously disadvantaged members of society now wield considerable political power and have the capability to resent, resist or reject policies that infringe their rights. The dynamics in the political landscape have culminated in a number of policy reforms in the country, an indication that civil society is concerned about their wellbeing. Unfortunately, political change does not culminate in economic power or wealth.

\section{Technological progress - Mobile phone or smartphone diffusion}

South Africa is among the strongest economies in Africa, and Inglesi-Lotz et al. (2014) underline the importance of technological progress in the economic growth of the country. Accordingly, it is not surprising that in 2014, the mobile phone diffusion rate of $89 \%$ (of which $34 \%$ are smartphones)

1.Stokvel: a rotating credit union. in South Africa was the highest in Africa (Poushter \& Oates 2015). Mobile broadband subscription in particular has experienced notable growth in Africa (Screen Africa 2014). With regard to the population in South Africa, only $16.4 \%$ in metropolitan areas, 9.2\% in urban areas and 2\% in rural areas have Internet access at home. However, because of the progressive improvement of mobile technology, 30.8\% of all households in South Africa, with $17.9 \%$ of rural households, go online using mobile devices (Statistics South Africa 2014). Furthermore, $84 \%$ of South African Internet users access the World Wide Web via mobile technology. This demonstrates the well-engineered South African mobile technological progress and the pervasiveness of mobile and smartphones (including tablets with mobile Internet access) being the most commonly used devices for Internet access.

The price of prepaid data bundles is rapidly falling because of the competitiveness in the market. In addition, smartphones are becoming progressively cheaper, which also contributes to an increase in data usage (Euromonitor 2015). Seventy-eight percent of South African Facebook users, for example, access this social media platform from their mobile and smartphones. Regarding the social network and micro-blogging service Twitter, $85 \%$ of people access this social media platform from their mobile phones (Bluemagnet 2014). South African companies are increasingly integrating social media marketing into their promotional mix and extending their social media budget, particularly for online content marketing and multimedia content (Poushter \& Oates 2015). One such South African industry that is progressively making use of the online service and application is the banking sector (Maduku 2014). Because of the aim of reducing the expenses that customers incur by visiting branch offices and the decrease in cost of mobile phone technology, Internet banking has become a popular alternative to traditional banking in South Africa (Karjaluoto, Mattila \& Pento 2002; Maduku 2014).

\section{Simplification of banking}

Considering the technological progress concerning mobile banking, mobile phones and smartphones as relatively young service communication channels offer potential in banking (Abbott 2015; Akturan \& Tezcan 2012; Laukkanen \& Lauronen 2005). According to Laukkanen and Pasanen (2008) and Akturan and Tezcan (2012), the main reasons for mobile banking adoption are convenience, access to banking services at any time of the day or night and minimisation of effort, time and consultation costs. Considering these facts, we acknowledge that South African mobile banking: (1) improves banking skills, (2) simplifies bank account maintenance, and (3) simplifies money transfers.

South African banks enable local citizens as well as foreigners to open bank accounts. To do this, South Africans must provide proof of income, address and identity; the most important criteria for a foreigner is a valid visa (AnswersAfrica 2013). However, because of the relatively open entry requirements 
(valid passport) and the accomplished tourist visa (90 days), South Africa is at odds with a high number of illegal immigrants who are not leaving the country after their visas have expired (Department of Home Affairs 2016). Many people regard the South African economy as an income-earning opportunity because the economy is classified as developing and highly successful in Africa (KEDO 2013). Thus, the need for money transfer to the home country for family support is high. Knowing the situation and the resulting illegal unbanked people, marketing practitioners recognising this trend offer money transfer systems for the unbanked (FinScope 2014). The method in which mobile banking addresses this system and (1) improves private banking skills, (2) simplifies bank account maintenance, and (3) simplifies money transfers is discussed in the following subsections.

\section{Improvement of banking skills}

Because private banking can include complex calculations, a bank account is, in most cases, also accompanied by a private banking consultant (Seidel \& Liebetrau 2015). While the service intensity varies based on salary level and the use of services, the philosophy of banks does not differ from the traditional customer concept of 'customer is king' (Seidel \& Liebetrau 2015). However, accomplished with the userfriendly interface of Web 2.0, online banking together with the 'do-it-yourself' mentality that is rewarded with no consulting costs has become a popular alternative to traditional face-to-face banking (Khrais 2015; Laforet \& Li 2005). Particularly for basic transactions, more and more customers are making use of online banking or mobile banking, which is being rapidly pitched by banks offering online banking websites and mobile banking applications with user-friendly interfaces (Khrais 2015; Raitani \& Vyas 2014). On the one hand, banks might reduce the consulting efforts required for basic transactions, and on the other hand, customers will gain more confidence concerning independent banking, therefore, improving their banking skills.

\section{Simplification of bank account maintenance}

As is apparent from the previous section, the user-friendly interface encourages people to adopt independent online/ mobile banking (Khrais 2015; Raitani \& Vyas 2014). The convenience of accessing a bank account at any time in order to track and administer finances might simplify the maintenance of private bank accounts. The most decisive point for the use of online or mobile banking is the timesaving aspect (Abbott 2015). Research concerning the effectiveness of smartphone applications illustrates the sophistication of tablet and smartphone use in life-improving matters (Couse \& Chen 2010; Granado-Font et al. 2015). Particularly in South Africa, where $84 \%$ of the Internet users access the World Wide Web via mobile technology, online or mobile banking might simplify bank account maintenance.

\section{Simplification of money transfers}

In earlier times, bank transactions were connected with much paper work and associated with time-consuming, in-house, drop-off costs. Moreover, the receiving party had to wait at least 1 or 2 days for transactions to be completed. Today, online or mobile banking allows customers to transfer money, including international transactions, within a day (Seidel \& Liebetrau 2015). Furthermore, clear, structured interfaces with explanatory images allow people even with little Internet experience, to make a transaction (Abbott 2015). Concerning Internet security, a transaction authentication number (TAN) serving as a one-time password, authorises the transaction. This TAN is mostly generated by a TAN-Generator or sent via a text message to the customer's mobile phone. Theoretically, this means online or mobile banking simplifies money transfers. This might be underlined, for example, by an online banking penetration of $90 \%$ in Norway, $85 \%$ in the Netherlands and a demonstrated $46 \%$ average in the European Union in 2015 (Statista 2015). In South Africa, there are currently four options for customers to access their accounts independently. Access can be via a computer, a tablet, a mobile phone or a smartphone. The five most popular banks in South Africa are ABSA, Capitec, First National Bank, Nedbank and Standard Bank. All provide mobile applications (Columinate 2015).

An upcoming option that simplifies money transfers is lowvalue, real-time, person-to-person payment, also known as mobile money (Abbott 2015). Real-time payments allow users to send or receive money with their feature phones, smartphones or tablet computers. Successfully adopted by more than 2500 US banks currently, the largest real-time, person-to-person payment network in the western world has been built, where mobile money has become rapidly popular. Particularly successful in introducing financial services to the lower-income class and to the unbanked, mobile money has become a popular banking instrument (Abbott 2015). Mobile money allows cashless consumers to transfer or pay varying amounts by using their mobile devices (Seidel \& Liebetrau 2015).

\section{Application of mobile money in sub-Saharan Africa}

As a consequence of the relatively high mobile phone density in SSA and the consumer demand that is driven by the need for secure cash transactions and the simplification of banking, mobile money has become rapidly popular (Laukkanen \& Pasanen 2008; Poushter \& Oates 2015). However, the adoption level differs significantly from country to country.

\section{M-Pesa}

An African example for mobile money adoption is the Kenyan SMS-based money transfer system known as M-Pesa, where M stands for Mobile and Pesa means money in KiSwahili. This system was launched in March 2007 by the telecommunication company Safaricom (Bengelstorff 2015). By using the mobile phone number as a virtual bank account number, M-Pesa allows individuals to deposit, save, send and withdraw money via their mobile phones. Figure 1 illustrates the simplicity of using M-Pesa (Bengelstorff 2015). Particularly for the unbanked, M-Pesa facilitates the exchange of money without physically having to visit a banking 


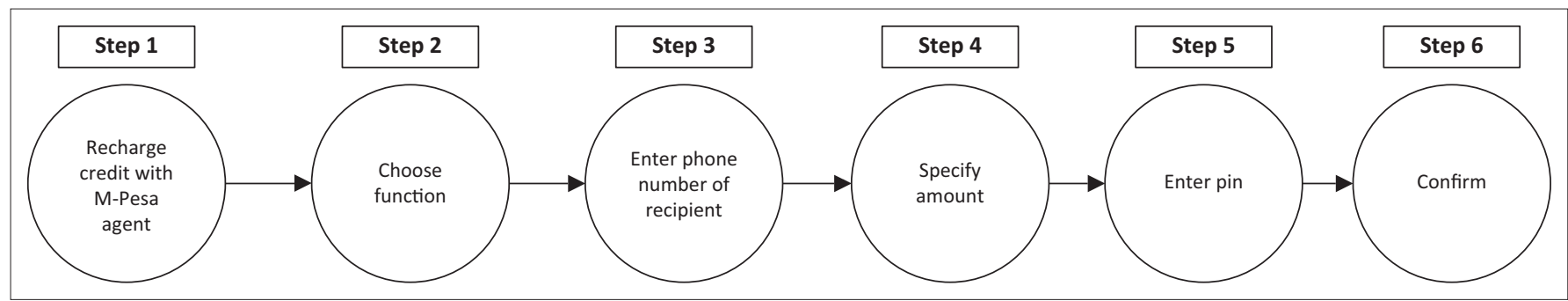

Source: Bengelstorff, A., 2015, A global success from Kenya, viewed 8 June 2016, from https://www.credit-suisse.com/us/en/news-and-expertise/banking/articles/news-and-expertise/2015/08/ en/a-global-success-from-kenya.html

FIGURE 1: Six payment steps of M-Pesa.

institution. Considering that most of Kenya's population are farmers who live in the countryside and are subjected to long distances to the nearest banking institution, the options to move cash are uncertain and risky. In contrast to methods such as sending cash with a bus driver or sending a postal money order, M-Pesa only requires a mobile phone with a Safaricom number to 'move cash' virtually over long distances, including transnationally. Thus, M-Pesa facilitates the safe storage and transfer of money. Furthermore, a reliable and safe storage mechanism may increase the household savings. In addition, M-Pesa allows families progressive mobility by sending members to high-paying jobs at distant locations. Another economic benefit of M-Pesa is that it increases the security of subscribers, particularly in the poorer segments of the population. For example, M-Pesa allows taxi drivers to deal with less cash, which has been found to be the reason for muggings. These facts might be underpinned by the research of Jack and Suri (2011) who explored the economics of M-Pesa in Kenya. According to their study, safety and ease of operation were the two main factors for adopting M-Pesa. Furthermore, they determined that the main reason for the non-use of M-Pesa was the simple fact of not owning a mobile phone (Jack \& Suri 2011).

Regarding mobile phone diffusion in Africa, South Africa and Nigeria are in the pole position. More precisely, $89 \%$ of South African and Nigerian adults owned a mobile phone in 2014. This $89 \%$ is subdivided into $34 \%$ smartphones in South Africa, 27\% smartphones in Nigeria and 55\% mobile phones in South Africa and 62\% mobile phones in Nigeria. Table 2 illustrates the top seven countries' diffusion of mobile phones and the use of mobile phones to perform payment transactions (Poushter \& Oates 2015).

Although $89 \%$ of South African adults owned mobile phones in 2014 , only $15 \%$ used them for mobile payments. Whereas users in Kenya exhibited a lower diffusion of mobile phones $(82 \%)$, but the use of mobile phones for payment transaction was the highest in Africa at $61 \%$. This inconsistency is discussed in the next section by comparing the South African M-Pesa with the Kenyan M-Pesa cases.

\section{South African M-Pesa versus Kenyan M-Pesa}

Two weeks after introducing M-Pesa in Kenya in 2007, Safaricom reported 20000 active users (Bengelstorff 2015;
Jack \& Suri 2011). This success story continued, exhibiting 20 million customers and 83000 agents by 2015 (Bengelstorff 2015; Jack \& Suri 2011). Today, on this basis, M-Pesa enables customers to pay electricity and water bills, obtain cash from an ATM, buy airline tickets, pay taxi drivers and take out small loans (Bengelstorff 2015; Jack \& Suri 2011). In contrast to Kenya, where Safaricom had the monopoly on mobile money during its launch, South Africa now exhibits a welldeveloped mobile banking system. More precisely, banks in South Africa provide reliable and easy access to banking services for all bank customers. This includes the lowerincome customers, reducing the number of unbanked to a minimum (Abbott 2015). In order to compete, almost every South African bank provides online banking and mobile banking applications. Besides this well-developed banking system, South Africa's financial system provides similar money transfer systems to M-Pesa for the unbanked. For example, Shoprite, Africa's largest food retailer, provides money transfers countrywide for R15 per transaction (Shoprite 2016). Different preconditions, poor distribution and poor marketing resulted in only 1 million users of M-Pesa in South Africa by the end of March 2015, which was labelled as a failure by the two main investors, Vodacom and Nedbank (Bengelstorff 2015). Consequently, Vodacom South Africa made the decision to discontinue the M-Pesa product with effect from 30 June 2016. Potential new customers were not able to register, and the facility of person-to-person payments to unregistered customers was terminated on 9 May 2016 (Tshabalala 2015).

On the basis of these two cases, it can be concluded that technical preconditions alone, in this case, a high mobile phone density, are not a guarantor for a successful launch and that environmental conditions should not be disregarded. The environmental conditions in the South African context that might deserve further research are discussed later.

\section{Zimbabwe's EcoCash}

Regarding international, real-time, person-to-person payments in SSA EcoCash, a mobile money transfer system launched in Zimbabwe in 2011, enables users to receive money from more than 50 international countries and territories (Dann 2014). EcoCash is a person-to-person mobile transfer system developed by Econet Wireless, a privately held telecommunications group with operations 
and investments in Africa, Europe, South America, North America and the East Asia Pacific Rim. The product, EcoCash, is based on the development of a mobile payment system to help NGOs make cash transfers to refugees after the Burundian Civil War. By adopting M-Pesa's obscure lines between telecommunication and banking and with the aim of helping the lower class or the unbanked to save, transfer and purchase cashless, EcoCash symbolises a Zimbabwean copy of the Kenyan M-Pesa (EcoCash 2016; Econet 2016; Leach 2014). In contrast to where M-Pesa failed to succeed in South Africa, EcoCash was confronted by three preconditions in Zimbabwe, similar to M-Pesa in Kenya. Firstly, the Econet product provider of EcoCash and the Safaricom product provider of M-Pesa were both telecommunication providers during their launches. With regard to the launch date of their mobile money products, both providers were nearmonopolistic players in their home market (Safaricom: 66.6\% in 2007; Econet: 70\% in 2011). Secondly, at the launch, both mobile phone penetration rates were high, with $40 \%$ for Safaricom in 2007 in Kenya and 74\% for Econet in 2011 in Zimbabwe (Africa\&middleeast 2011). Thirdly, with 70\% unbanked in Zimbabwe in 2011 and a population that had lost trust in the banks, Zimbabwe's environmental preconditions for an independent banking service were high (Mangudya 2016). Because of these three preconditions and the advantage of technological progress over 4 years, EcoCash had 2.4 million subscribers in the first year, that is, 320000 more subscribers than M-Pesa in its first year in Kenya (Kabweza 2012; Techzim 2011). Accompanied by a mobile penetration of $95.4 \%$ in the last quarter of 2015, the mobile money service, EcoCash, rapidly expanded in Zimbabwe. With 5.8 million subscribers in 2016 and 26500 agents across Zimbabwe, EcoCash has become the largest financial service provider in the country (Gambanga 2016a). In addition to the national success, EcoCash allows users to send money to Zimbabwe from 57 countries worldwide (EcoCash 2016).

It is apparent that the environmental preconditions must be considered wisely when launching a mobile money service system. Furthermore, M-Pesa and EcoCash illustrated that mobile money services improve banking skills, particularly of the unbanked, simplify bank account maintenance and simplify money transfers in SSA. How mobile money services influence the adoption of information and communication technology (ICT) in South Africa is discussed in the next section.

\section{Influence of information and communication technology on the adoption of mobile money}

As illustrated by the three real-world examples above and underlined by Van de Ven (1986) and Rogers (2010), the implementation of ICT is always associated with organisational, environmental and individual changes. These changes and the accomplished implication challenges are theorised by researchers and practitioners in the research area that focuses on the acceptance and adoption of
TABLE 3: Sub-Saharan Africa literature concerning mobile money technology acceptance theories.

\begin{tabular}{llll}
\hline Main theory & Content & Research design & Author(s) and year \\
\hline TAM & $\begin{array}{l}\text { Explores the motivations of } \\
\text { the unbanked to adopt } \\
\text { mobile banking in Ghana }\end{array}$ & $\begin{array}{l}\text { Qualitative } \\
\text { research }\end{array}$ & Tobbin 2012 \\
TAM & $\begin{array}{l}\text { Examines the factors that } \\
\text { influence the adoption of } \\
\text { M-banking in Kenya }\end{array}$ & $\begin{array}{l}\text { Quantitative } \\
\text { research }\end{array}$ & $\begin{array}{l}\text { Lule, Omwansa } \\
\text { and Waema 2012 }\end{array}$ \\
$\begin{array}{l}\text { TAM; Diffusion } \\
\text { of Innovation }\end{array}$ & $\begin{array}{l}\text { Investigates the key } \\
\text { factors that influence the } \\
\text { Ghanaian consumers' } \\
\text { acceptance of mobile } \\
\text { money transfer technology }\end{array}$ & $\begin{array}{l}\text { Quantitative } \\
\text { research }\end{array}$ & Tobbin 2012 \\
TAM & $\begin{array}{l}\text { Investigates the success } \\
\text { factors attributable to the } \\
\text { use of mobile payments } \\
\text { by micro-business operators } \\
\text { in Kenya }\end{array}$ & $\begin{array}{l}\text { Quantitative } \\
\text { research }\end{array}$ & Mbogo 2010 \\
\hline
\end{tabular}

TAM, Technology Acceptance Model

Source: Luarm, P. \& Lin, H., 2005, 'Towards an understanding of the behavioral intention to use mobile banking', Computers in Human Behaviour 21(6), 873-891. https://doi. org $/ 10.1016 /$ j.chb.2004.03.003

technology (Korpelainen 2011). According to Korpelainen, the most cited theories are the Technology Acceptance Model (TAM), the Theory of Reasoned Actions, Diffusion of Innovations and the Theory of Planned Behaviour. These theories mainly explore individual technology acceptance by analysing the organisation and the implementation of ICT.

Regarding the acceptance of the technology of mobile money in Africa, Table 3 outlines the literature using technology acceptance theories.

As can be seen in Table 3, TAM is a popular theory for the technology acceptance of mobile money in Africa. The TAM describes perceived usefulness and perceived ease of use as fundamental determinants to examine behavioural intentions concerning the use of technology and its acceptance. It is described by Luarm and Lin (2005) as the most widely accepted model in information system literature. Concerning the literature above and the use of the TAM, the two fundamental determinants mentioned above were extended with individual research perceptions. For example, Tobbin (2012) added the economic factor and perceived trust as two additional factors in order to explore the acceptance of mobile banking technology by the unbanked. On the basis of TAM, Lule et al. (2012) generated a generic mobile banking adoption framework. The literature above concludes without exception that TAM is a suitable technology acceptance theory for research in the mobile money field.

Taking these facts into account, the authors of this article illustrate how mobile money systems influence the adoption of ICT in South Africa with the help of: (1) organisational changes, (2) environmental changes, and (3) individual changes.

\section{Organisational changes}

Regarding organisational changes, the approach of Vodacom and Nedbank to implement M-Pesa in South Africa showed that not only environmental requirements but also organisational tasks were neglected (Bengelstorff 2015). According to Tshabalala (2015), the marketing and 
TABLE 4: Meta-analysis of findings.

\begin{tabular}{|c|c|c|}
\hline Empirical study & Findings & References \\
\hline Kenya's M-Pesa & $\begin{array}{l}\text { Kenya's mobile money project is regarded as one of the highly successful projects to have emerged in sub- } \\
\text { Saharan Africa. }\end{array}$ & Bengelstorff (2015); Jack and Suri (2011). \\
\hline South Africa's M-Pesa & $\begin{array}{l}\text { Tshabalala (2015) asserts that the South African version of M-Pesa was a huge failure project, resulting in its } \\
\text { closure. }\end{array}$ & Tshabalala (2015) \\
\hline Zimbabwe's EcoCash & $\begin{array}{l}\text { Compared to South Africa, Zimbabwe's EcoCash is regarded as a second success story after Kenya's M-Pesa. } \\
\text { Reports indicate that EcoCash is the main mobile money transaction system in Zimbabwe. }\end{array}$ & Econet (2016); Leach (2014) \\
\hline Present study & $\begin{array}{l}\text { Mobile banking is the ideal alternative to traditional online banking. The failure of the South African project } \\
\text { should be the basis for developing user-friendly and effective mobile banking platforms. The South African } \\
\text { mobile money project is a clear indication that implementation of such systems is difficult because of a variety } \\
\text { of factors. These factors include technology acceptance behaviour, risk associated with cyberspace } \\
\text { transactions, technological infrastructure and lack of education relating to banking services. The Kenya and } \\
\text { Zimbabwe success stories should act as sources of motivation for financial institutions and other players to } \\
\text { propagate mobile banking. More efforts are required to educate users of mobile banking services so as to } \\
\text { increase the uptake. Kenya has done and continues to excel in that aspect because of visible educational } \\
\text { campaigns, while the current economic situation in Zimbabwe is compelling the financial and } \\
\text { telecommunications industry to devise ways to curb shortages of money supply. }\end{array}$ & - \\
\hline
\end{tabular}

organisation of the agents, which are key points of the M-Pesa service system, were weakly implemented. As progressively claimed by the banks, the comparatively high bank account diffusion and accomplished low unbanked population share the organisational changes for mobile money adoption in South Africa. For example, Capitec Bank Holdings Limited provides unstructured supplementary service data, a mobile banking system applicable to almost every mobile phone. Because of the rapid technological progress, the smartphone applications provided by all large banks in South Africa have become particularly popular in the urban areas (Abbott 2015). Therefore, it can be said that organisational changes concerning mobile money systems in South Africa have a decentralised role, starting with the banks.

\section{Environmental changes}

Despite the influence of the international oil crisis in the 1970s, the international sanctions to end apartheid from 1985 onwards, democratisation in 1994 and the financial crisis from 2007 onwards, the economy of South Africa has been ranked in the top five in Africa continuously (Inglesi-Lotz et al. 2014). According to Inglesi-Lotz et al., growthaccounting calculations elucidate the progressive increase and importance of technological growth in contrast to the production factors of capital and labour during the 2000s. As reported by Debsu, Little, Tiki, Guagliardo, and Kitron (2016), the recent expansion of mobile phone use introduces the technological change in Africa. With the recent increased technical infrastructure, mobile technology that was predominantly used in urban areas has expanded to relatively remote areas. As illustrated in the previous sections, the use of ICTs has rapidly increased connectivity and aided in prosperity for Africa (Debsu et al. 2016). As one of the industrialised and westernised countries in Africa, environmental changes improved mobile banking skills in the rural areas.

\section{Individual changes}

With regard to $89 \%$ mobile phone diffusion 2014 in South Africa (Poushter \& Oates 2015), the acceptance of mobile technology is high. However, the acceptance of the technology regarding mobile money is comparatively low at $15 \%$ (Poushter \& Oates 2015). This low acceptancy might be reasoned by the relatively well-developed bank account diffusion. Nonetheless, future research is required to verify this speculation. Because of the decentralisation of mobile money providers and the large variety of them in comparison with other SSA countries, South Africa does not possess a high unbanked population. However, it is the corporation of the individual mobile money service provider that complicates transactions. More precisely, for individuals, it is more convenient to use a mobile money service when their transaction partner has the same mobile money service provider (Abbott 2015). Accordingly, the individual changes in South Africa are because of the advanced organisational and environmental progress in comparison with the remaining SSA countries and the smooth cooperation between the several mobile money service providers, not the actual mobile money service.

\section{Findings}

The findings from this study are illustrated in Table 4. A meta-analysis summary of findings from Kenya's mobile money project, South Africa's Vodacom M-Pesa and Zimbabwe's EcoCash project are presented in Table 4.

\section{Limitations and suggestions for future research}

This research is limited by the literature concerning mobile money in SSA and concentrating on the South African mobile money service market. Because this research is a literature survey, no quantitative or qualitative data were raised. Concerning future research, the sections above illustrate that because of a lack of academic literature concerning mobile banking in South Africa, both qualitative and quantitative research is required. More precisely, it would be promoting to investigate if an existing bank account has an influence on the adoption of mobile money in South Africa. This could be done through qualitative research (interviewing specialist) or quantitative research, taking TAM as a basic conceptual framework.

\section{Conclusion}

Whereas prior mobile banking research studies have explored consumers' intentions to adopt mobile banking services, the purpose of this research was to review 
existing research on mobile banking diffusion and investigate the adoption of mobile banking in SSA. In addition, the aim of this article was to provide suggestions for future research in the mobile money field in South Africa. The findings from this study revealed that both Kenya and Zimbabwe have recorded success stories in the areas of mobile banking, whereas the South African story is a sad note to discuss. This reveals that there is a great need to educate South African users on the importance of information communication technologies. The rate of ICT adoption in South Africa is relatively low despite a high number of mobile cellular phone users. In addition, private and public sector institutions have a big role to play to impart knowledge to users on the need to accept and embrace information communication technologies because the world has become a global village. Resistance to accepting and use of technologies may impede success in communities that were previously disadvantaged. The findings from this study also revealed that innovation is not a preserve of a rich economy, but when the economic and political conditions are stringent, entrepreneurial skills enhance innovation. The Zimbabwean political and economic situation is a clear example. Zimbabwe's Econet Wireless Holdings partnered and developed the highly successful EcoCash system because of the acute shortage of money supply. This system was ideal to alleviate traditional banking processes where clients spent time in banking halls queuing for cash or enquiries. EcoCash is establishing its operations in South Africa because there are many Zimbabwean nationals living in South Africa who send money back to Zimbabwe. Researchers established that South Africa is confronted with environmental, organisational and individual challenges compared to other SSA countries (23.5\%). Consequently, future research exploring these different challenges could be conducted. With reference to research findings, it is difficult to deploy mobile money systems transnationally because of differences in the adoption and acceptance of information and communication technologies.

\section{Acknowledgements \\ Competing interests}

The authors declare that they have no financial or personal relationship(s) that may have inappropriately influenced them in writing this article.

\section{Authors' contributions}

Both the authors contributed significantly by drafting the article and revising it for important intellectual content. J.M.C. came up with the concept of developing the article on mobile banking and its success/failure in South Africa, by providing fundamental issues that formed the structure of the article. In addition, J.M.C. ensured that the article was edited through third party services. B.H. was responsible for collating the article through the collection of various pieces of literature on the research article. B.H. was also responsible for final editing and production of this presentation.

\section{References}

Abbott, D., 2015, SA ripe for a mobile banking revolution, viewed 17 May 2016, from http://www.fin24.com/Tech/Opinion/SA-ripe-for-a-mobile-bankingrevolution-20150223

Africa\&middleeast, 2011, Kenya: Major African mobile market, viewed 14 June 2016, from http://www.africantelecomsnews.com/resources/AfricaOpp_Kenya.html\#Table2

Aker, J.C. \& Mbiti, I.M., 2010, 'Mobile phones and economic development in Africa', The Journal of Economic Perspectives 24(3), 207-232. https://doi.org/10.1257/ jep.24.3.207

Akhter, S.H., 2015, 'Impact of internet usage comfort and internet technical comfort on online shopping and online banking', Journal of International Consumer Marketing 27(3), 207-219. https://doi.org/10.1080/08961530.2014.994086

Akturan, U. \& Tezcan, N., 2012, 'Mobile banking adoption of the youth market: Perceptions and intentions', Marketing Intelligence \& Planning 30(4), 444-459. https://doi.org/10.1108/02634501211231928

AnswersAfrica, 2013, How to open a bank account in South Africa, viewed 13 May 2016, from http://answersafrica.com/how-to-open-a-bank-account-in-southafrica.html

Barbesino, P., Camerani, R. \& Gaudino, A., 2005, 'Digital finance in Europe: Competitive dynamics and online behaviour', Journal of Financial Services Marketing 9(4) 329-343. https://doi.org/10.1057/palgrave.fsm.4770164

Bengelstorff, A., 2015, A global success from Kenya, viewed 8 June 2016, from https:// www.credit-suisse.com/us/en/news-and-expertise/banking/articles/news-andexpertise/2015/08/en/a-global-success-from-kenya.html

Bluemagnet, 2014, The state of social media in South Africa 2014, viewed 20 February 2016, from http://www.bluemagnet.co.za/the-state-of-social-media-in-southafrica-2014/

Brown, M., 2014, Ad reaction: Marketing in a multiscreen world, viewed 20 February 2016, from https://www.millwardbrown.com/adreaction/2014/\#/

BusinessTech, 2016, How much money you need to be middle class in South Africa viewed 11 May 2016, from http://businesstech.co.za/news/wealth/111285/howmuch-money-you-need-to-be-middle-class-in-south-africa/

Columinate, 2015, Columinate 2015 internet banking SITEisfaction survey shows improvement from local banks, viewed 16 May 2016, from http://www. bizcommunity.com/Article/196/19/128105.html.

Couse, L.J. \& Chen, D.W., 2010, 'A tablet computer for young children? Exploring its viability for early childhood education', Journal of Research on Technology in Education 43(1), 75-96. https://doi.org/10.1080/15391523.2010.10782562

Dann, C., 2014, Will EcoCash eat the banks' lunch? How mobile payments filled a financial services gap in Zimbabwe, viewed 14 June 2016, from http://www. tfreview.com/news/regions/will-ecocash-eat-banks'-lunch-how-mobilepayments-filled-financial-services-gap-zimbabw

Debsu, D., Little, P., Tiki, W., Guagliardo, S. \& Kitron, U., 2016, 'Mobile phones for mobile people: The role of information and communication technology (ICT) mobile people: The role of information and communication technology (ICT) Peoples 20(1), 35-61. https://doi.org/10.3197/np.2016.200104

Department of Home Affairs (DHA), 2016, Passport holders who are exempt from visas for South Africa, viewed 13 May 2016, from http://www.dha.gov.za/index.php/ immigration-services/exempt-countries

EcoCash, 2016, EcoCash products \& services, viewed 14 June 2016, from https://www. econet.co.zw/ecocash/ecocash-products-and-services

Econet, 2016, About us, viewed 14 June 2016, from http://www.econetwireless.com/ about_econet.php.

Euromonitor, 2015, Mobile phones in South Africa, viewed 20 February 2016, from http://www.euromonitor.com/mobile-phones-in-south-africa/report

Ferreira, J., 2016, South Africa GDP growth rate 1993-2016, viewed 10 May 2016 from http://www.tradingeconomics.com/south-africa/gdp-growth

FinScope, 2014, FinScope South Africa 2014, viewed 13 May 2016, from http://www. banking.org.za/docs/default-source/financial-inclusion/finscope/finscopesa-2014.pdf

Gambanga, N., 2016a, EcoCash handles $\$ 6,6$ billion in transactions, dominates Zimbabwean payments field, viewed 14 June 2016, from http://www.techzim. co.zw/2016/06/ecocash-handles-66-billion-transactions-dominateszimbabwean-payments-field/\#.V2QTYFexaqA

Gambanga, N., 2016b, Latest POTRAZ report shows leaps in LTE \& increase in Zimbabwe's internet penetration, viewed 1 March 2017, from http://www. techzim.co.zw/2016/01/latest-potraz-report-shows-increase-in-zimbabwesinternet-penetration/

Gambanga, N., 2016c, Mobile money subscribers in Zimbabwe increase by $7.1 \%$ viewed 1 March 2017, from http://www.techzim.co.zw/2016/01/mobile-moneysubscribers-zimbabwe-increase-7-1/

Granado-Font, E., Flores-Mateo, G., Sorlí-Aguilar, M., Montaña-Carreras, X., FerreGrau, C., Barrera-Uriarte, M.L., 2015, 'Effectiveness of a smartphone application and wearable device for weight loss in overweight or obese primary care patients: Protocol for a randomised controlled trial', BMC Public Health 15(1), 531. https:// doi.org/10.1186/s12889-015-1845-8

Inglesi-Lotz, R., Van Eyden, R. \& Du Toit, C.B., 2014, 'The evolution and contribution of technological progress to the South African economy: Growth accounting and Kalman filter application', Energy Policy 39(6), 3690-3696. https://doi. org/10.1016/j.enpol.2011.03.078

Internetlivestats, 2016, Internet users 2016, viewed 10 January 2017, from http:// www.internetlivestats.com/internet-users/ 
Internet Society, 2015, Global internet report 2015, viewed 25 April 2017, from http:// www.internetsociety.org/globalinternetreport/\#main-content

Jack, W. \& Suri, T., 2011, Mobile money: The economics of M-Pesa (No. w16721), National Bureau of Economic Research.

Kabweza, L.S.M., 2012, EcoCash adds 200,000 more subscribers in a month (Growth stats since launch), viewed 14 June 2016, from http://www.techzim.co. zw/2012/04/ecocash-adds-200000-subscribers-in-a-month-growth-trend-sincelaunch/\#.V2QWpVexaqA

Karjaluoto, H., Mattila, M. \& Pento, T., 2002, 'Factors underlying consumer attitude formation towards online banking in Finland', International Journal of Bank Marketing 20(6), 261-272. https://doi.org/10.1108/02652320210446724

KEDO, 2013, South Africa's immigration problem, viewed 13 May 2016, from http:// fordhampoliticalreview.org/south-africa's-immigration-problem/

Khrais, L.T., 2015, 'Highlighting the vulnerabilities of online banking system', Journal of Internet Banking \& Commerce 20(3), n.p. https://doi.org/10.4172/12045357.1000120

Koech, J., 2012, 'Bringing banking to the masses, one phone at a time,' Economic Letter 7.

Korpelainen, E., 2011, Theories of ICT system implementation and adoption -A critical review, Working Paper 2011, Department of Industrial Engineering and Management, Alto University Publication series (1), 14-17.

Laforet, S. \& Li, X., 2005, “"Consumers” attitudes towards online and mobile banking in China', International Journal of Bank Marketing 23(5), 362-380.

Laukkanen, T. \& Lauronen, J., 2005, 'Consumer value creation in mobile banking services', International Journal of Mobile Communications 3(4), 325-338. https:// doi.org/10.1504/IJMC.2005.007021

Laukkanen, T. \& Pasanen, M., 2008, 'Mobile banking innovators and early adopters: How they differ from other online users', Journal of Financial Services Marketing How they differ from other online users', Journal of Financia
$13(2), 86-94$. https://doi.org/10.1057/palgrave.fsm. 4760077

Leach, A., 2014, 'Zimbabwe's Econet wireless and the making of Africa's first cashless society', viewed 14 June 2016, from http://www.theguardian.com/globaldevelopment-professionals-network/blog/2014/aug/18/econet-wirelesszimbabwe-cashless-society

Luarm, P. \& Lin, H., 2005, 'Towards an understanding of the behavioral intention to use mobile banking', Computers in Human Behaviour 21(6), 873-891. https://doi. org/10.1016/j.chb.2004.03.003

Lule, I., Omwansa, T.K. \& Waema, T.M., 2012, 'Application of technology acceptance model (TAM) in m-banking adoption in Kenya', International Journal of Computing and ICT Research 6(1), 31-43.

Maduku, D.K., 2014, 'Predicting retail banking customers' attitude towards internet banking services in South Africa', Southern African Business Review 17(3), 76-100.

Mangudya, J.P., 2016, January 2016: Monetary policy statement, viewed 14 June 2016 from http://www.rbz.co.zw/assets/monetary-policy-statement-january-2016.pdf.

Mankiw, N.G., 2015, Macroeconomics, 9th edn., International Edition, Macmillan Education, Cengage Learning, Boston, MA

Mbogo, M., 2010, 'The impact of mobile payments on the success and growth of microbusiness: The case of M-Pesa in Kenya', Journal of Language, Technology \& Entrepreneurship in Africa 2(1), 182-203. https://doi.org/10.4314/jolte.v2i1.51998
Moloi, R., 2014, Exploring the barriers to the sustainability of Spaza shops in Atteridgeville, Tshwane, PhD dissertation, Unisa, Pretoria.

Online Dictionary, 2017, Defining online banking, viewed 24 January 2017, from http://www.dictionary.com.html

Poushter, J. \& Oates, R., 2015, 'Cell phones in Africa: Communication lifeline texting most common activity, but mobile money popular in several countries', viewed 22 April 2016, from http://www.pewglobal.org/2015/04/15/cell-phones-in-africacommunication-lifeline/

Raitani, S. \& Vyas, V., 2014, 'An exploratory study of factors influencing the e-loyalty of online banking consumers', Journal of Bank Management 13(3), 34.

Rogers, E.M., 2010, Diffusion of innovations, Simon and Schuster, New York.

Screen Africa, 2014, Africa's digital penetration in 2014, viewed 20 February 2016, from http://www.screenafrica.com/page/news/mobile-tv/1639686-Africasdigital-penetration-in-2014\#.VshvBDaxYdV

Seidel, M. \& Liebetrau, A., 2015, Banking \& innovation 2015: Ideen und erfolgskonzepte von experten für die praxis, Springer-Verlag, Berlin.

Shoprite, 2016, Money transfer service, viewed 27 April 2016, from http://web shoprite.co.za/money-market/money-transfers.html

Statista, 2015, Online banking penetration in selected European markets in 2015, viewed 15 May 2016, from http://www.statista.com/statistics/222286/onlinebanking-penetration-in-leading-european-countries/

Statistics South Africa, 2014, General household survey 2014, viewed 20 February 2016, from http://www.statssa.gov.za/publications/P0318/ P03182014.pdf

Techzim, 2011, Econet announces the launch of EcoCash, Press Release, viewed 14 June 2016, from http://www.techzim.co.zw/2011/09/econet-announces-thelaunch-of-ecocash/\#.V2QVdVexaqA.

Tobbin, P., 2012, 'Towards a model of adoption in mobile banking by the unbanked: A qualitative study', Info 14(5), 74-88. https://doi.org/10.1108/1463669 1211256313

Tshabalala, S., 2015, Why South Africa's largest mobile network, Vodacom, failed to grow M-Pesa, viewed 14 June 2016, from http://qz.com/467887/why-southafricas-largest-mobile-network-vodacom-failed-to-grow-mpesa/

Ubuntu Connectors Club (UCC), 2016, Working together for success, viewed 14 June 2016, from http://www.ubuntuconnectors.co.za/contributions_5.html.

Van de Ven, A.H., 1986, 'Central problems in the management of innovations', Management Science 32(5), 590-607. https://doi.org/10.1287/mnsc.32.5.590

Van Wyk, M.W.T., 2012, Mobile banking in south and beyond: SABRIC conference, n.p., Midrand.

Vaupel, M. \& Kaul, V., 2016, Die geschichten des geldes: Von der kaurischnecke zum goldstandard - So entwickelte sich das finanzsystem, Börsenbuch Verlag, Kulmbach.

Visagie, J., 2013, Who are the middle class in South Africa? Does it matter for policy?, viewed 11 May 2016, from http://www.econ3×3.org/article/who-are-middleclass-south-africa-does-it-matter-policy 